\title{
Correction to: Statistical analysis plan for management of hypertension and multiple risk factors to enhance cardiovascular health in Singapore: the SingHypertension pragmatic cluster randomized controlled trial
}

John C. Allen Jr ${ }^{1 *}$, Benjamin Halaand ${ }^{1,2}$, Rupesh M. Shirore ${ }^{3}$, Tazeen H. Jafar ${ }^{3^{*}}$ and for SingHypertension Study Group

Correction to: Trials (2021) 22:66

https://doi.org/10.1186/s13063-020-05016-4

Following publication of the original article [1], we were notified that a citation was inadvertently added in the abstract. The publisher apologizes for any inconvenience.

The original article has been corrected.

\section{Author details}

${ }^{1}$ Centre for Quantitative Medicine, Duke-NUS Medical School, Level 6,

Academia, 20 College Road, Singapore, Singapore. ${ }^{2}$ Division of Biostatistics, Population Health Sciences, University of Utah, Salt Lake City, USA. ${ }^{3}$ Program in Health Services \& Systems Research, Duke-NUS Medical School, 8 College Road, Singapore, Singapore.

Published online: 08 February 2021

\section{Reference}

1. Allen JC Jr, et al. Statistical analysis plan for management of hypertension and multiple risk factors to enhance cardiovascular health in Singapore: the SingHypertension pragmatic cluster randomized controlled trial. Trials. 2021; 22:66. https://doi.org/10.1186/s13063-020-05016-4.

The original article can be found online at https://doi.org/10.1186/s13063020-05016-4.

*Correspondence: john.allen@duke-nus.edu.sg; tazeen.jafar@duke-nus.edu.sg ${ }^{1}$ Centre for Quantitative Medicine, Duke-NUS Medical School, Level 6, Academia, 20 College Road, Singapore, Singapore

${ }^{3}$ Program in Health Services \& Systems Research, Duke-NUS Medical School, 8 College Road, Singapore, Singapore

Full list of author information is available at the end of the article

(c) The Author(s). 2021 Open Access This article is licensed under a Creative Commons Attribution 4.0 International License, which permits use, sharing, adaptation, distribution and reproduction in any medium or format, as long as you give appropriate credit to the original author(s) and the source, provide a link to the Creative Commons licence, and indicate if changes were made. The images or other third party material in this article are included in the article's Creative Commons licence, unless indicated otherwise in a credit line to the material. If material is not included in the article's Creative Commons licence and your intended use is not permitted by statutory regulation or exceeds the permitted use, you will need to obtain permission directly from the copyright holder. To view a copy of this licence, visit http://creativecommons.org/licenses/by/4.0/ The Creative Commons Public Domain Dedication waiver (http://creativecommons.org/publicdomain/zero/1.0/) applies to the data made available in this article, unless otherwise stated in a credit line to the data. 